\title{
Local regulatory factors controlling folliculogenesis in pigs
}

\author{
S. A. Tonetta and G. S. diZerega \\ Livingston Reproductive Biology Laboratory. Department of Obstetrics and Gynecology. \\ University of Southern California School of Medicine, Los Angeles, CA 90033, USA
}

Keywords: folliculogenesis; intraovarian control; pig

\section{Introduction}

Although many excellent reviews have summarized follicular development from the perspective of gonadotrophin-induced follicular differentiation and steroid secretion (Richards, 1980), the process of selection and dominance of ovulatory follicles during each ovarian cycle remains poorly understood. The present review will focus primarily on the role of intragonadal substances in the regulation of follicular maturation. Since previous summaries have considered follicular maturation with respect to prostaglandins (Aksel et al., 1977), insulin, somatomedins (Adashi et al., 1985), relaxin (Bagnell et al., 1987), lipoproteins (Gwynne \& Strauss, 1982) and gonadotrophinreleasing hormone ( $\mathrm{GnRH})$ (Knecht et al., 1983), details of these topics will not be repeated here. Rather, we will review the growing body of data from experiments using predominantly follicular tissue and cells from the sow which address the intraovarian regulation of folliculogenesis.

Gonadotrophins play a role in initiation and maintenance of follicular growth, selection of dominant follicles and their maturation to preovulatory status. Evidence for this is derived from changes in blood concentrations of follicle-stimulating hormone (FSH) and luteinizing hormone (LH), concomitant alterations in the number and type of gonadotrophin receptors in granulosa and theca cells, and from the secretion of steroidal and non-steroidal products by these cells in response to gonadotrophin stimulation. However, follicular growth cannot be accounted for entirely by the changing concentrations of gonadotrophins. Rather, the developing responsiveness of follicles to stimulation by FSH and LH results from changes in the production of and alterations in follicular sensitivity to intraovarian paracrine and/or autocrine factors (Tonetta \& diZerega, 1986). In this context, gonadotrophins are necessary, but not sufficient by themselves, to account for the ovarian cycle. In recent years, several intragonadal regulators have been identified and characterized which can alter follicular maturation. In addition to the well-known paracrine factors discussed below, additional paracrine regulators have been identified but their function is still uncertain (see Tonetta \& diZerega, 1989).

\section{Inhibin}

Ovarian follicular fluid from many species including sows contains a non-steroidal factor which can suppress the secretion of FSH from rat pituicytes (Shander et al., 1980). Inhibin activity was correlated with concentrations of gonadotrophins and steroids in serum to identify potential physiological functions. Recently, several reviews were published detailing the isolation and characterization of inhibin (Ying, 1987, 1988).

Inhibin was identified in the follicular fluid of pigs as well as other species (Ying, 1988). Inhibin is produced in vitro by granulosa cells from pig follicles (Anderson \& DePaolo, 1981). In the sow, levels of inhibin in serum increase during the follicular phase with the increase in inhibin continuing for approximately 6 days (Fig. 1; Hasegawa et al., 1988). Concentrations of FSH in serum are inversely related to inhibin values during this time. Concentrations of inhibin decrease with the 
LH surge and then show two peaks during the luteal phase, indicating that the corpora lutea, in addition to the granulosa cells, are a source of inhibin in this species.

Inhibin has also been identified by immunohistochemistry or nuclease assays in non-gonadal tissues (Crawford et al., 1987). Although the physiological role of extragonadal inhibin is unknown, it may regulate local cellular activity.

\section{Activin}

Side fractions from h.p.l.c. purification of follicular fluid for inhibin produced stimulatory effects on FSH release from pituicytes in vitro. It was discovered that this stimulatory activity was due to dimers of the $\beta$-subunits of inhibin; $\beta_{A} \beta_{A}$ and $\beta_{A} \beta_{B}$ (Ling et al., 1986). These compounds were named activin and activin- $A$, respectively. The two activins are equipotent in their ability to enhance secretion of FSH in a dose-dependent manner in vitro without affecting the secretion of LH.

Although activin alone appears to have little effect on gonadal function, it can alter gonadotrophin-stimulated events (Hutchinson et al., 1987). Activin can enhance FSH-stimulated induction of $\mathrm{LH}$ receptors, but has little effect on progesterone secretion in sheep granulosa cells. Receptors for activin on granulosa cells of rats are characterized by linear Scatchard plots with the number of receptors greatly enhanced after gonadotrophin stimulation (Sugino et al., 1988). A physiological role for these proteins in follicular maturation remains unclear.

\section{Follistatin}

Follistatin, a single peptide chain of molecular weight $32000-35000$ distinct from inhibin and activin, has been isolated from pig follicular fluid. However, like inhibin, follistatin can inhibit the release of FSH, but not $\mathrm{LH}$, from cultures of pituitary cells (Ueno et al., 1987; Ying et al., 1987). Incubation of pituitary cells with both inhibin and follistatin results in an additive inhibition of FSH release. After exposure of pituicytes to follistatin, levels of intracellular FSH decrease, but not to the extent seen with inhibin. This suggests that follistatin is involved in the suppression of release as opposed to synthesis of FSH. Therefore, regulation of synthesis and secretion of FSH from the pituitary is regulated by GnRH from the hypothalamus and steroidal and non-steroidal factors from the ovary.

\section{Follicle regulatory protein}

A protein referred to as follicle regulatory protein (FRP), which inhibits aromatase activity in granulosa cells, has been identified in follicular fluid from the sow and other species (review, diZerega et al., 1988). FRP purified to homogeneity from pig and human follicular fluid has similar molecular weights (15000) and isoelectric points ( $\mathrm{pH} \mathrm{4.5).} \mathrm{Since} \mathrm{FRP} \mathrm{does} \mathrm{not} \mathrm{inhibit} \mathrm{release} \mathrm{of}$ FSH from rat pituicytes in vitro or in vivo (diZerega et al., 1988), it has properties distinctly different from inhibin and follistatin.

FRP is secreted by pig granulosa cells from small and medium follicles, but not from cultured pig theca cells (Tonetta et al., 1988b). Granulosa cells from follicles of preovulatory size show a marked reduction in secretion of FRP. These findings suggest that, as the follicle luteinizes, changes in secretion of FRP accompany alterations in steroidogenesis.

High levels of intrafollicular FSH reduce the action of FRP in pig granulosa cells and may allow for increased granulosa aromatization and production of oestrogen. Schreiber \& diZerega (1986) reported that exposure of rat granulosa cells to increasing concentrations of FSH counteracted the 


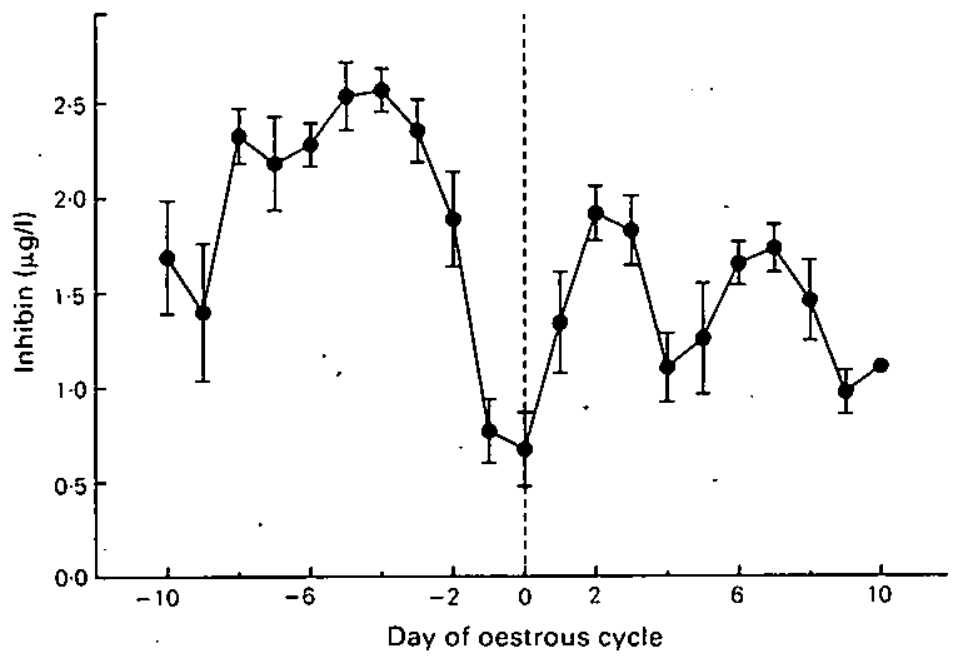

Fig. 1. Mean plasma concentrations ( \pm s.e.m.) of inhibin during the oestrous cycle of pigs. Day $0=$ day of ovulation. (Reproduced from Hasegawa et al., 1988.)

FRP-associated inhibition of aromatase (Fig. 2). FRP can modulate other FSH-responsive activities in pig granulosa cells (e.g. induction of $\mathrm{LH} / \mathrm{hCG}$ receptors, cAMP formation and $3 \beta-\mathrm{HSD}$ activity). These data indicate that preovulatory follicles may be recruited to develop due to early exposure to FSH, resulting in reduced sensitivity to and/or production of FRP by those follicles. In contrast, exposure to elevated amounts of FRP results in suppressed follicular maturation.
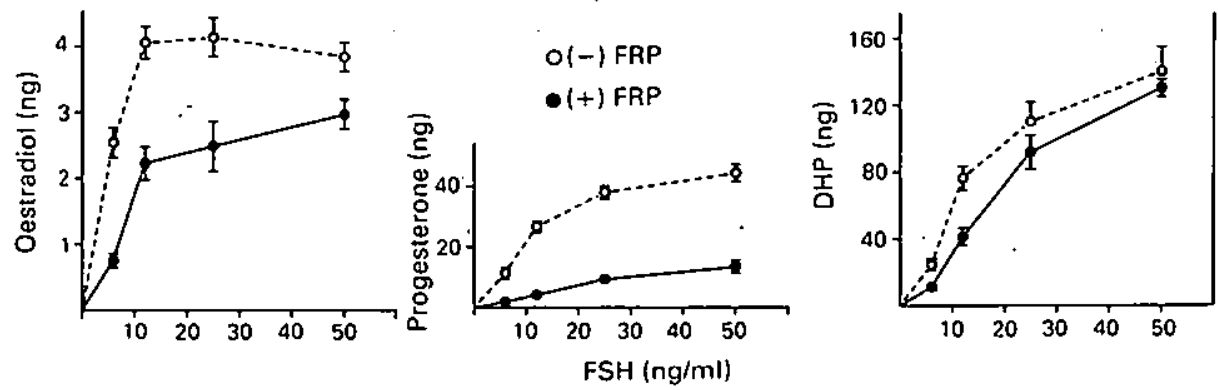

Fig. 2. Effect of follicle regulatory protein (FRP) on production of oestrogen, progesterone and 20a-dihydroprogesteronc (DHP) after stimulation with FSH. Values are mean \pm s.e.m.; $n=3$ separate expcriments. (Reproduced from Schreiber \& diZerega, 1986.)

FRP inhibits secretion of progesterone as well as oestradiol by granulosa cells from sows (diZerega et al., 1988). When FRP is added to pig granulosa cells, there is a dose-dependent decrease in secretion of progesterone and microsomal 3ß-HSD activity (diZerega et al., 1988).

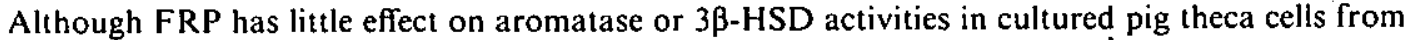
medium follicles, it can decrease the hCG-induced increase in aromatase activity (Tonetta $e t$ al., 1988a). In contrast, FRP inhibits basal thecal aromatase activity and the hCG-induced increase in $3 \beta$-HSD and aromatase activities in large follicles. Therefore, the effects of FRP on thecal function depend upon the stage of follicular maturation.

FRP can also alter gonadotrophin binding and adenylate cyclase activity in granulosa cells. Specific binding of hCG to granulosa cells after administration of FSH was decreased by FRP (diZerega et al., 1988). This reduction in hCG binding was prevented by the co-administration of 
FSH. In addition, FRP decreased adenylate cyclase activity in pig granulosa cells but this decrease was again prevented when cells were preincubated with FSH before treatment with FRP (diZerega et al., 1988). The effect of FRP therefore appears to be mediated, in part, through FSH-responsive adenylate cyclase rather than by a generalized alteration in cytosolic events.

The effects of FRP on granulosa activities reflect an interplay between the systemic endocrine and local paracrine systems. The ability of FRP to modulate the follicular response to FSH is consistent with the hypothesis that paracrine effectors are principal mediators of folliculogenesis in the presence of gonadotrophins.

\section{Glycosaminoglycans}

Although the primary glycosaminoglycans (GAGs) in follicular fluid are chondroitin sulphate, heparan sulphate and dermatan sulphate (review, Ax \& Bellin, 1988), concentrations of these factors differ during follicular development (Table 1). Granulosa cells from small follicles of cows bind more heparan sulphate than do cells from large follicles (Bushmeyer et al., 1985) while concentrations of chondroitin sulphate decrease with increasing follicular size in cattle and pig follicles (Bellin \& Ax, 1984). Since levels of chondroitin sulphate are higher in individual cow follicles which are atretic by histological and steroidal criteria, chondroitin sulphate may be a biochemical marker for atresia (Bellin \& Ax, 1984).

Table 1. Concentrations (mean and s.e. for triplicate estimations) of follicular fluid GAG from small $(5 \mathrm{~mm})$, medium $(6-10 \mathrm{~mm})$, and large $(10-20 \mathrm{~mm})$ follicles of cows (reproduced from Ax \& Bellin, 1988)

\begin{tabular}{|c|c|c|c|c|c|}
\hline \multirow[b]{2}{*}{$\begin{array}{l}\text { Follicle } \\
\text { size }\end{array}$} & \multirow[b]{2}{*}{$\begin{array}{c}\text { Follicular } \\
\text { oestradiol } \\
(\mathrm{ng} / \mathrm{ml})\end{array}$} & \multicolumn{2}{|c|}{$\begin{array}{l}\text { Heparin sulphate } \\
\quad(\mathrm{mg} / \mathrm{ml})\end{array}$} & \multicolumn{2}{|c|}{$\begin{array}{l}\text { Dermatan sulphate } \\
\qquad(\mathrm{mg} / \mathrm{ml})\end{array}$} \\
\hline & & $\begin{array}{l}\text { Heparin } \\
\text { standard }\end{array}$ & $\begin{array}{l}\text { Follicular } \\
\text { standard }\end{array}$ & $\begin{array}{l}\text { Chondroitin } \\
\text { sulphate } \\
\text { standard }\end{array}$ & $\begin{array}{l}\text { Follicular } \\
\text { standard }\end{array}$ \\
\hline Small & $\begin{array}{c}6.8 \text { (atretic) } \\
60 \cdot 7 \text { (not atretic) }\end{array}$ & $\begin{array}{l}1.44(0.22) \\
0.87(0.06)\end{array}$ & $\begin{array}{l}0.24(0.09) \\
0.10(0.02)\end{array}$ & $\begin{array}{l}1.18(0.42) \\
0.47(0.04)\end{array}$ & $\begin{array}{l}1.29(0.08) \\
0.79(0.01)\end{array}$ \\
\hline Medium & $\begin{array}{c}1.5 \text { (atretic) } \\
133 \text { (not atretic) }\end{array}$ & $\begin{array}{l}0.52(0.02) \\
0.04(0.01)\end{array}$ & $\begin{array}{l}0.06(0.02) \\
0.07(0.02)\end{array}$ & $\begin{array}{l}2.00(0.64) \\
0.86(0.35)\end{array}$ & $\begin{array}{l}1 \cdot 16(0.09) \\
0.80(0.06)\end{array}$ \\
\hline Large & $\begin{array}{c}2 \cdot 3 \text { (atretic) } \\
295 \text { (not atretic) }\end{array}$ & $\begin{array}{l}0.26(0.05) \\
0.10(0.05)\end{array}$ & $\begin{array}{l}0.08(0.01) \\
0.05(0.01)\end{array}$ & $\begin{array}{l}0.82(0.01) \\
0.89(0.13)\end{array}$ & $\begin{array}{l}0.89(0.31) \\
0.52(0.04)\end{array}$ \\
\hline
\end{tabular}

Levels of GAGs are inversely proportional to concentrations of oestradiol and progesterone in follicular fluid (Ax \& Bellin, 1988). Since concentrations of heparan and chondroitin sulphates decrease before the time when oestradiol increases, a reduction in the concentrations of these GAGs might be necessary for follicular growth and maturation (Ax \& Bellin, 1988). The decrease in the levels of GAGs during follicular development may be directly mediated by gonadotrophins.

The addition of GAGs to cuitures of granulosa cells of rats inhibits the number of LH receptors and the stimulation of adenylate cyclase (Ax \& Bellin, 1988). These findings indicate that the effect is a local one, with granulosa cells secreting chondroitin and heparan sulphates which act at the granulosa cell surface (Ax \& Bellin, 1988).

\section{Growth factors}

Insulin-like growth factors (IGFs) promote both replication and differentiation of cultured granulosa cells (review, Hammond et al., 1983; Adashi et al., 1985). IGFs have an effect on virtually 
every aspect of granulosa cell function including enhancement of FSH-stimulated production of progestagen, oestrogen, cAMP and proteoglycans, as well as LH receptor induction (Hammond et al., 1983; Adashi et al., 1985). In monolayers of pig theca cells, IGF-I increases basal and gonadotrophin-induced secretion of progesterone and further enhances hCG-induced synthesis of androstenedione and testosterone (Caubo et al., 1989). However, IGF-I decreases secretion of oestradiol in cultured pig theca. Additionally, specific receptors for IGF-I have been demonstrated on pig theca and granulosa cells (Caubo \& Tonetta, 1989; Hylka et al., 1989). Although IGF-I is involved in the differentiation of granulosa cells, the number of IGF-I receptors on granulosa cells remains constant throughout follicular maturation, manifesting the same affinity and capacity. The possible involvement of ovarian IGFs in follicular development in vivo has also been suggested by measurements of IGF-I in follicular fluid and culture media from granulosa cells. Hsu \& Hammond (1987) reported that gonadotrophins, oestrogen, and cAMP stimulated the secretion of immunoreactive IGF-I by ovarian cells (Fig. 3).

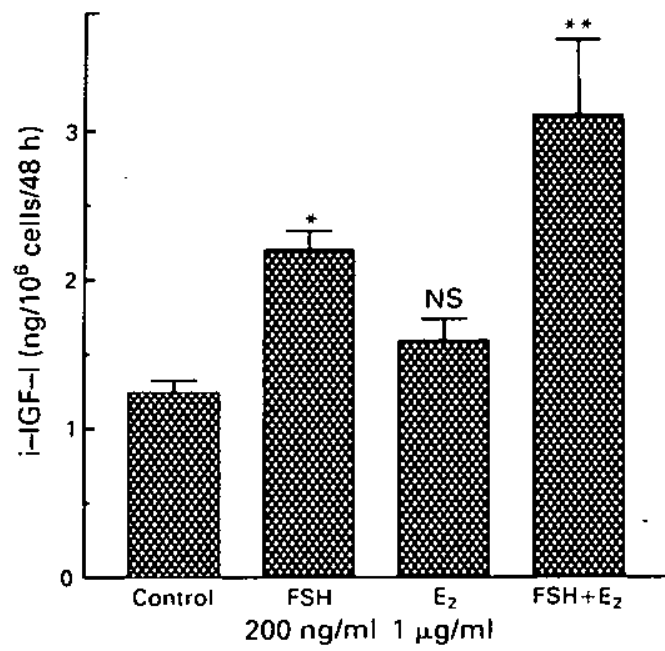

Fig. 3. Effects of FSH, oestradiol, and their combination on secretion of immunoreactive IGF-I from pig follicles. Treatment groups include control, FSH $(200 \mathrm{ng} / \mathrm{ml})$, oestradiol $17 \beta(1 \mu \mathrm{g} / \mathrm{ml})$, or FSH + oestradiol $\left(E_{2}\right)$. The values represent $\mathrm{i}$-IGF-I secreted between Days 5 and 7 , normalized by cell counts determined on Day 7 (mean \pm s.e.m.; $n=6$ ). ${ }^{*} P<0.05,{ }^{* *} P<0.01$ (vs control). (Reproduced from Hsu \& Hammond, 1987.)

Epidermal growth factor (EGF), present in many tissues including ovarian theca (Skinner et al., 1987b), can stimulate maturation of granulosa cells, but inhibits steroid production. EGF inhibits production of oestradiol, and causes a dose-dependent inhibition of progesterone production in rat granulosa cells (Hsueh et al., 1981). EGF has also been shown to inhibit production of both inhibin and progesterone in bovine granulosa cells, but increases synthesis of DNA and protein (Franchimont et al., 1986). In pig theca cells, EGF inhibits production of oestradiol but has little effect on secretion of progesterone or androgens (Caubo et al., 1989). EGF may therefore selectively modulate steroidogenesis in theca and granulosa cells.

Transforming growth factor beta (TGF- $\beta$ ) has been identified in follicular fluid and bovine theca cells (Skinner $e t$ al., 1987a). TGF- $\beta$ increases $\left[{ }^{3} \mathrm{H}\right.$ ]thymidine incorporation by granulosa cells of the rat (Dodson \& Schomberg, 1987), but decreases incorporation in pig granulosa cells (Mondschein et al., 1988). TGF- $\beta$ enhances FSH-stimulated differentiation of rat granulosa cells (Dodson \& Schomberg, 1987), has a bifunctional effect on FSH-stimulated induction of LH receptors in granulosa cells (Dodson \& Schomberg, 1987; Knecht et al., 1987), and augments FSHstimulated aromatase activity and cAMP production (Knecht $e t$ al., 1987). TGF- $\beta$ increases basal 
and FSH-enhanced secretion of progesterone in rat granulosa cells (Dodson \& Schomberg, 1987), but inhibits EGF-stimulated production of IGF-I (Fig. 4) as well as basal and FSH-stimulated production of progesterone in pig granulosa cells (Mondschein \& Hammond, 1988; Mondschein et al., 1988).

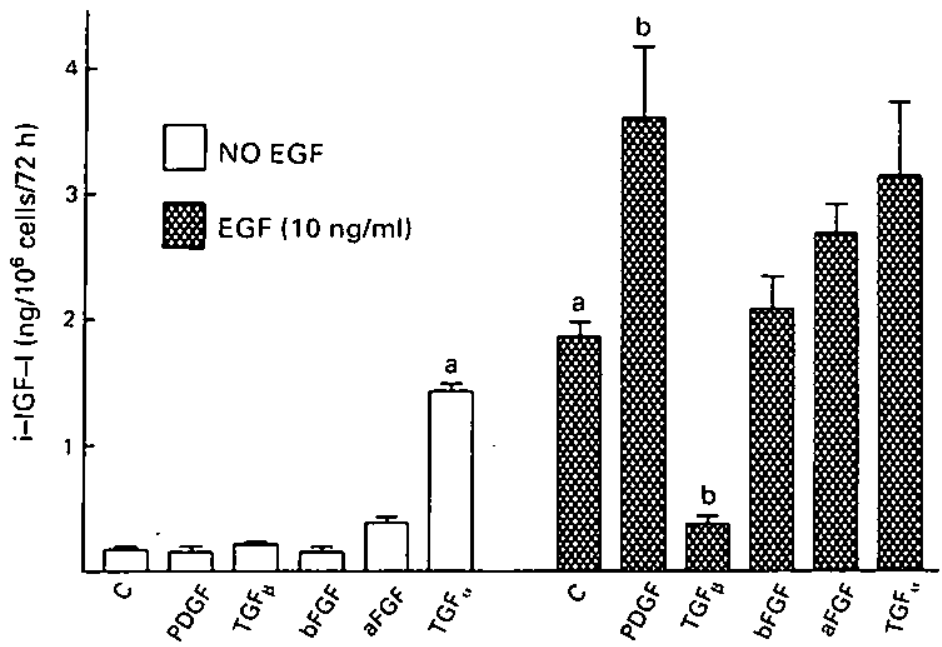

Fig. 4. Effects of various growth factors alone and in combinations with EGF on production of immunoreactive IGF-I from pig follicles. $\mathrm{C}=$ control; $\mathrm{a}=$ differs from no EGF control $(P<0.05) ; \mathrm{b}=$ differs from EGF control $(P<0.05)$. (Reproduced from Mondschein \& Hammond, 1988.)

TGF- $\beta$ can also modulate steroidogenesis in thecal cells (Caubo et al., 1989). In theca cells from large pig follicles, high doses of TGF. $\beta$ inhibited basal secretion of progesterone and androstenedione, whereas lower doses prevented the hCG-induced increase in these steroids (Caubo $\mathrm{et} \mathrm{al}$., 1989). Basal secretion of testosterone was not affected by TGF- $\beta$, but stimulation of testosterone by hCG was prevented by this growth factor. In contrast to granulosa cells, basal and hCG-induced secretion of oestradiol from theca cells was enhanced by TGF- $\beta$ (Caubo et al., 1989).

Basic fibroblast growth factor, produced by the corpus luteum and involved in mitogenic and angiogenic activity in these cells, was identified in bovine granulosa cells (Neufeld et al., 1987). Basic FGF from granulosa cells was bioactive, stimulating proliferation of capillary endothelial or granulosa cells. Therefore, this factor may be involved in proliferation of granulosa cells and vascularization of the theca during follicular development.

Growth factors produced by both the theca and granulosa appear to locally modulate steroidogenesis and differentiation of the follicle.

\section{Plasminogen activator}

Tissue type (t-PA) and urokinase type (u-PA) plasminogen activators are produced by follicular cells (review, Abisogun et al., 1988). Granulosa cells produce predominantly the tissue-type enzyme while theca cells secrete primarily u-PA, the production of which is regulated by gonadotrophins. By measuring both tissue content and secreted PA activity, Reich et al. (1986) found that, although t-PA and $u-P A$ are both produced by follicular cells, t-PA accounted for $\sim 80 \%$ (basal) and $\geq 90 \%$ (LH/FSH-treated) of the activity in the follicle (Fig. 5). FSH-stimulated t-PA production from 
granulosa cells is retained in the extracellular matrix surrounding the cell (Knecht, 1988). Therefore, this PA may function as an autocrine regulator of granulosa cell differentiation, including alterations in the structural changes which occur in the follicle during maturation.

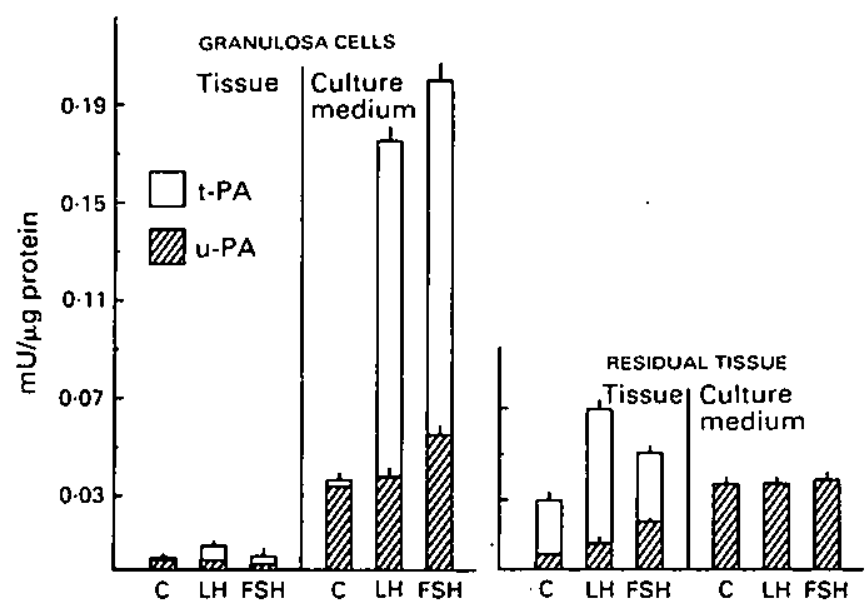

Fig. 5. Zymographic analysis of plasminogen activator produced by pig granulosa and theca cells in culture. Granulosa cells and theca were cultured in the presence of the gonadotrophins indicated. Extracts and culture media were subjected to zymographic analysis. $\mathrm{C}=$ controls. (Reproduced from Reich et al., 1986.)

Ovulation appears to require both types of plasminogen activators for rupture of the follicle and unimpeded passage of the ovum out of the ovary (Abisogun et al., 1988). There is considerable evidence linking granulosal production of plasminiogen activator to ovulation, including: (1) increases in production, reaching a maximum around the time of follicle rupture; (2) induction of the enzyme in preovulatory follicles; and (3) induction in vitro by FSH and LH.

Plasminogen activator activity has been demonstrated in the cumulus-oocyte complexes of hypophysectomized, diethylstilboestrol-treated rats (Liu $e t$ al., 1986). Activity of t-PA but not of u-PA or PA inhibitor, was identified in the cytoplasm of denuded, primary oocytes from preantral follicles of the rat. The t-PA and u-PA activities were identified in cumulus-oocyte complexes, but only t-PA activity was enhanced by FSH and forskolin. Since rat cumulus cells have FSH receptors, the increase in t-PA after administration of FSH may be involved in the disruption of gap-junctions and therefore communication between the oocyte and cumulus cells before ovulation.

\section{Oocyte maturation}

When oocytes are removed from their intrafollicular environment and cultured, many spontaneously reinitiate meiosis, suggesting the presence of an inhibitor of oocyte maturation within the follicle (review, Eppig, 1987). One candidate for the prevention of meiosis is cAMP. Inhibition of meiosis by pig follicular fluid in mouse and rat oocytes was dramatically synergized by the addition of dibutyryl cAMP or by drugs enhancing production of cAMP (Eppig, 1987). In addition, continuous exposure to CAMP prevents spontaneous oocyte maturation. Elevating or maintaining concentrations of cAMP in.the oocyte with membrane-permeable analogues of CAMP, with calcium ionophores or with inhibitors of phosphodiesterase maintains meiotic arrest (Preston et al., 1987). 


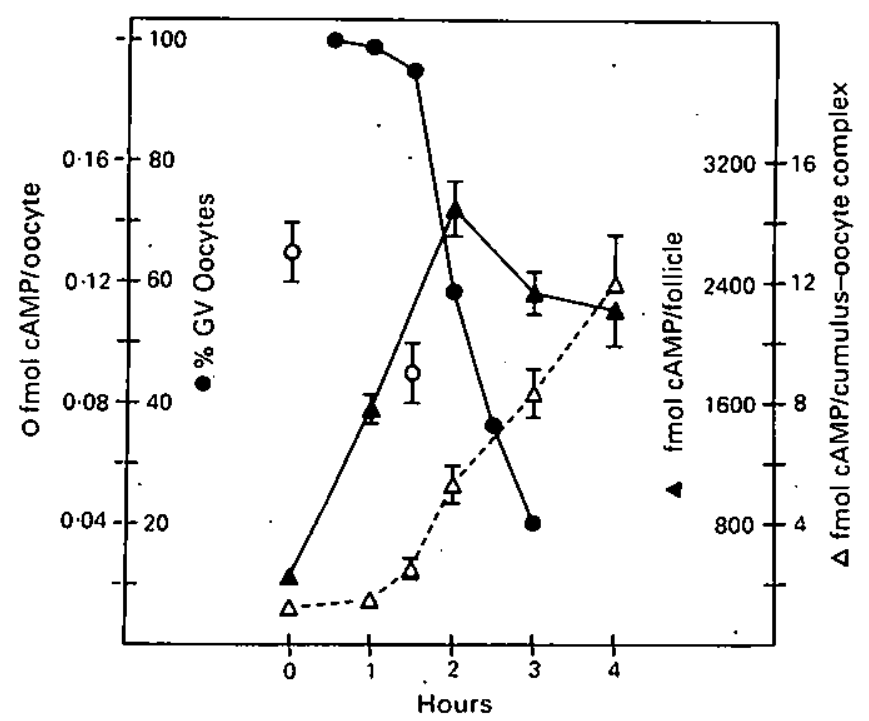

Fig. 6. Time course for GVBD and CAMP values in follicles, cumulus-oocyte complexes and oocytes during resumption of meiosis in vivo. Data for each experiment were pooled. Levels of cAMP in oocytes $(O)$, cumulus-oocyte complexes $(\Delta)$ and follicles $(\Theta)$ were determined by RIA. Data for GVBD are expressed as \% GV oocytes. The number of samples of cumulusoocyte complexes analysed at $0,1 \cdot 0,1 \cdot 5,2: 0,3 \cdot 0$ and $4 \cdot 0 \mathrm{~h}$ was $13,21,10,27,26$ and 8 respectively. The total number of individual follicles analysed at $0,1 \cdot 0,2 \cdot 0,3 \cdot 0$ and $4 \cdot 0 \mathrm{~h}$ was 12,15 , 21, 23 and 18, respectively. (Reproduced from Schultz et al., 1983.)

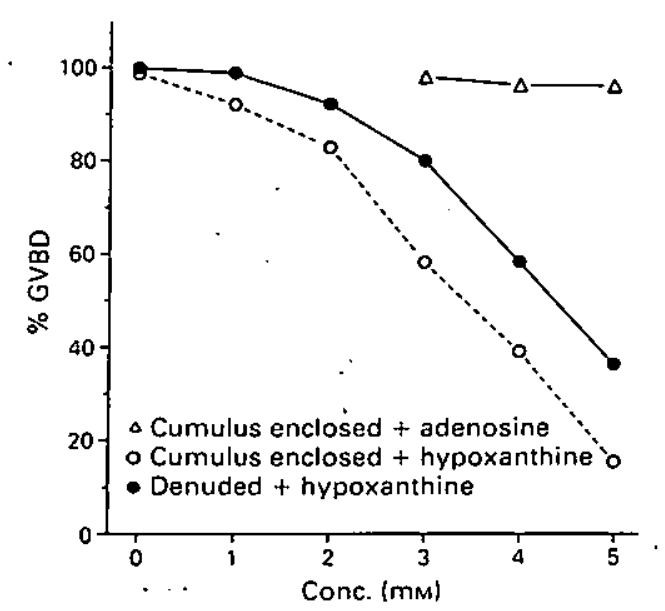

Fig. 7. The effect of hypoxanthine and adenosine on GVBD in mouse oocytes. The triangles indicate cumulus cell-enclosed oocytes incubated in medium containing various concentrations of adenosine. All groups were incubated for $3 \mathrm{~h}$ and then assessed for GVBD. The number of oocytes per group ranged from 224 to 580 . (Reproduced from Eppig et al., 1985.)

Moreover, a decrease in amounts of cAMP in the oocyte is coincident with a commitment to undergo germinal vesicle breakdown (GVBD) (Schultz et al., 1983) (Fig. 6). This decrease in cAMP could result from secretion of cAMP and/or the action of phosphodiesterase within the oocyte. It appears, therefore, that cAMP may serve as an inhibitory signal at the level of the oocyte. 
In addition to cAMP, purines have been found to prevent the resumption of meiosis. Pig follicular fluid contains a substance of low molecular weight that maintains meiotic arrest in mouse oocytes and is greatly augmented by cAMP (Eppig et al., 1985). Hypoxanthine is a component of this low molecular weight fraction of pig follicular fluid (Eppig, 1987). However, human and bovine follicular fluids are essentially devoid of hypoxanthine, indicating that this purine does not universally regulate oocyte maturation, but rather that regulation of purine metabolism may be directly involved in maintenance of meiotic arrest (Eppig, 1987). Adenosine works synergistically with hypoxanthine to maintain meiotic arrest (Eppig et al., 1985). Incubation of cumulus cellenclosed oocytes in hypoxanthine results in the maintenance of meiotic arrest (Fig. 7). In addition, adenosine is a metabolic precursor of hypoxanthine. Since concentrations of these purines do not appear to decrease immediately before hCG-induced GVBD, it is unlikely that a decrease in the concentration of these purines in follicular fluid initiates oocyte maturation. If hypoxanthine, adenosine, and/or their derivatives are physiologically important for maintaining meiotic arrest, their concentrations within the oocyte may be more important than their concentrations in the extracellular follicular fluid. Therefore, GVBD may result from: (1) metabolic conversion of the purines to inactive derivatives; (2) transport of hypoxanthine and/or adenosine (or their metabolites) out of the oocyte; and/or (3) a gonadotrophin-induced stimulus that bypasses the inhibitory influence of these purines (Eppig, 1987).

\section{Conclusions}

Although FSH and LH play major roles in follicular maturation, their control of the follicular microenvironment may be permissive. FSH and LH increase cAMP and diacylglycerol which trigger intracellular events. In addition, locally-produced steroids modulate production of intracellular proteins, cellular division, metabolism and steroidogenesis itself. Since steroids act by increasing the production of mRNAs and subsequent protein synthesis, the secretion of these intrafollicular substances and rate of their synthesis can be locally regulated. Therefore, these intrafollicular compounds, along with steroids, affect local cellular responses and the direct ovarian response to gonadotrophins.

\section{References}

Abisogun, A.O., Reich, R., Miskin, R. \& Tsafriri, A. (1988) Proteolytic processes at ovulation. In Development and Function of the Reproductive Organs, pp. 285-293. Eds M. Parvinen. I. Huhtaniemi \& L. J. Pelliniemi. Ares-Serono Symposia, Rome.

Adashi, E.Y., Resnick, C.E., D'Ercole, A.J., Svoboda, M.E. \& Van-Wyk, J.J. (1985) Insulin-like growth factors as intraovarian regulators of granulosa cell growth and function. Endocrine Rev. 6, 400-420.

Aksel, S., Schomberg, D.W. \& Hammond, C.B. (1977) Prostaglandin $\mathrm{F}_{2} \mathrm{a}$ production by the human ovary. Obstet. Gynecol. 50, 347-350.

Anderson, L.D. \& DePaolo, L.V. (1981) Control of inhibin secretion from the ovary. In Intragonadal Regulation of Reproduction, pp. 343-349. Eds P. Franchimont \& C. P. Channing. Academic Press, New York.

Ax, R.L. \& Bellin, M.E. (1988) Glycosaminoglycans and follicular development. J. Anim. Sci. 66, 32-49.

Bagnell, C.A., Ainsworth, L., Bryant-Greenwood, G.D. \& Greenwood, F.C. (1987) Follicular relaxin: A role in the paracrine control of ovarian function. In The Control of Follicle Development, Ovulation and Luteal Function: Lessons From In Vitro Fertilization, pp.
35-44. Eds F. Naftolin \& A. H. DeCherney. Raven Press, New York.

Bellin, M.E. \& Ax, R.L. (1984) Chondroitin sulfate: an indicator of atresia in bovine follicles. Endocrinology $114,428-434$.

Bushmeyer, S.M., Bellin, M.E. \& Ax, R.L. (1985) Specific binding of $\left[{ }^{3} \mathrm{H}\right]$ heparin to bovine granulosa cell membranes. Molec. cell. Endocr. 42, 135-144.

Caubo, B. \& Tonetta, S.A. (1989) Binding sites for IGF-I identified on theca cells from large porcine follicles. In Growth Factors and the Ovary, pp. 169-174. Ed. A. Hirshfield. Plenum Press, New York.

Caubo, B., DeVinna, R.S. \& Tonetta, S.A. (1989) Regulation of steroidogenesis in theca cells from porcine follicles by growth factors. Endocrinology. 125, $321-326$.

Crawford, R.J., Hammond, V.E., Evans, B.A., Coghlans, J.P., Haralambidis, J. \& Hudson, B. (1987) a-Inhibin gene expression occurs in the ovine adrenal cortex, and is regulated by adrenocorticotropin. Molec. Endocr. 1, 699-706.

diZerega, G.S., Fujimori, K., Tonetta, S.A., Chari, S., Ledwitz-Rigby, F., Rigby, B. \& Rodgers, K.E. (1988) Experience with follicle regulatory protein as an 
inhibitor of folliculogenesis and spermatogenesis in vivo. In Nonsteroidal Gonatal Factors, pp. 235-248. Eds G. D. Hodgen, Z. Rosenwaks \& J. M. Spieler. The Jones Institute Press, Norfolk.

Dodson, W.C. \& Schomberg, D.W. (1987) The effect of transforming growth factor $\beta$ on follicle stimulating hormone-induced differentiation of cultured rat granulosa cells. Endocrinology 120, 512-516.

Eppig, J.J. (1987) Factors controlling mammalian oocyte maturation. In The Primate Ovary, pp. 77-90. Ed. R. L. Stouffer. Plenum Press, New York.

Eppig, J.J., Ward-Bailey, P.F. \& Coleman, D.L. (1985) Hypoxanthine and adenosine in murine ovarian follicular fluid: concentrations and activity in maintaining oocyte meiotic arrest. Biol. Reprod. 33, 1041-1049.

Franchimont, P., Hazee-Hagelstein, M.T., CharletRenard, C. \& Jaspar, J.M. (1986) Effect of mouse epidermal growth factor on DNA and protein synthesis, progesterone and inhibin production by bovine granulosa cells in culture. Acta endocr.. Copenh. $111,122-127$.

Gwynne, J.T. \& Strauss, J.F., III (1982) The role of lipo-proteins in steroidogenesis and cholesterol metabolism in steroidogenic glands. Endocrine Rev. 3, 299-329.

Hammond, J.M., Yoshida, K., Veldhuis, J.D., Rechler, M.P. \& Knight, A.P. (1983) Intrafollicular role of insulin-like growth factors. In Factors Regulating Ovarian Function, pp. 197-202. Eds G. S. Greenwald \& P. F. Terranova. Raven Press, New York.

Hasegawa, Y., Miyamoto, K., Iwamura, S. \& Igarashi, M. (1988) Changes in serum concentrations of inhibin in cyclic pigs. J. Endocr. 118, 211-219.

Hsu, C.J. \& Hammond, J.M. (1987) Gonadotropins and estradiol stimulate immunoreactive insulin-like growth factor-I production by porcine granulosa cells in vitro. Endocrinology 120, 198-207.

Hsueh, A.J.W., Welsh, T.H. \& Jones, P.B.C. (1981) Inhibition of ovarian and testicular steroidogenesis by epidermal growth factor. Endocrinology 108, 2002-2004.

Hutchinson, L.A., Findlay, J.K., de Vos, F.L. \& Robertson, D.M. (1987) Effects of bovine inhibin transforming growth factor- $\beta$ and bovine activin- $A$ on granulosa cell differentiation. Biochem. Biophys. Res. Commun. $146,1405-1412$.

Hylka, V.W., Caubo, B. \& Tonetta, S.A. (1989) Analysis of binding sites for IGF-I on membranes from granulosa cells of small, medium and large porcine follicles. In Growth Factors in the Ovary, pp. 163-168. Ed. A. Hirshfield. Plenum Press, New York.

Knecht, M. (1988) Plasminogen activator is associated with the extracellular matrix of ovarian granulosa cells. Molec. cell. Endocr. 56, 1-9.

Knecht, M., Ranta, T., Naor, Z. \& Catt, K.J. (1983) Direct effects of GnRH on the ovary. In Factors Regulating Ovarian Function, pp. 225-243. Eds G. S. Greenwaild \& P. F. Terranova. Raven Press, New York.

Knecht, M., Feng, P. \& Catt, K.J. (1987) Bifunctional role of transforming growth factor $\beta$ during granu. losa cell development. Endocrinology 120, 1243-1249.

Ling, N., Ying, S-Y., Ueno, N., Shimasaki, S., Esch, F., Hotta, M. \& Guillemin, R. (1986) A homodimer of the $\beta$-subunits of inhibin A stimulates the secretion of pituitary follicle stimulating hormone. Biochem. Biophys. Res. Commun. 138, 1129-I 137.

Liu, Y-X., Ny, T., Sarkar, D., Loskutoff, D. \& Hsueh, A.J.W. (1986) Identification and regulation of tissue plasminogen activator activity in rat cumulus-oocyte complexes. Endocrinology 119, 1578-1587.

Mondschein, J.S. \& Hammond, J.M. (1988) Growth factors regulate immunoreactive insulin-like growth factor I (ilGF-1) production by cultured porcine granulosa cells. Endocrinology 123, 46j-468.

Mondschein, J.S., Canning, S.F. \& Hammond, J.M. (1988) Effects of transforming growth factor- $\beta$ on the production of immunoreactive insulin-like growth factor I and progesterone on $\left[{ }^{3} \mathrm{H}\right]-1$ hymidine incorporation in porcine granulosa cell cultures. Endocrinology 123, 1970-1976.

Neufeld, G., Ferrara, N., Schweigerer, L., Mitchell, R. \& Gospodarowicz, D. (1987) Bovine granulosa cells produce basic fibroblast growth factor. Endocrinology' 121, 597-603.

Preston, S.L., Parmer, T.G. \& Behrman, H.R. (1987) Adenosine reverses calcium-dependent inhibition of follicle-stumulating hormone action and induction of maturation in cumulus-enclosed rat oocytes. Endocrinology 120, 1346-1353.

Reich, R., Miskin, R. \& Tsafriri, A. (1986) Intrafollicular distribution of plasminogen activators and their hormonal regulation in vitro. Endocrinology 119, |588-|60|.

Richards, J.S. (1980) Maturation of ovarian follicles: actions and interactions of pituitary and ovarian hormones on follicular cell differentiation. Physiol. Rev. 60, 51-89.

Schreiber, J.R. \& diZerega, G.S. (1986) Porcine follicular fluid protein(s) inhibits rat ovary granulosa cell steroidogenesis. Am. J. Obstet. Gynecol. 155, $1281-1288$.

Schultz, R.M., Montgomery, R.R. \& Belanoff, J.R. (1983) Regulation of mouse oocyte meiotic maturation: implication of a decrease in oocyte cAMP and protein dephosphorylation in commitment to resume meiosis. Devl Biol. 97, 264-272.

Shander, D., Anderson, L.D., Barraclough, C.A. \& Channing, C.P. (1980) Interactions of porcine follicularfluid with ovarian steroids and luteinizing hormonereleasing hormone on the secretion of luteinizing hormone and follicle-stimulating hormone by cultured pituitary cells. Endocrinology 106, 237-242.

Skinner, M.K., Keski-Oja, J., Osteen, K.G. \& Moses, H.L. (1987a) Ovarian thecal cells produce transforming growth factor- $\beta$ which can regulate granulosa cell growth. Endocrinology 121, 786-792.

Skinner, M.K., Lobb, D., \& Dorrington, J.H. (1987b) Ovarian thecal-interstitial cells produce an epidermal growth factor-like substance. Endocrinology 121, 1892-1899.

Sugino, H., Nakamura, T., Hasegawa, Y., Miyamoto, K., Abe, Y., Eto, Y., Shibaitt, H., Titani, K. \& Igarashi, M. (1988) Effects of inhibin and activin on granulosa cell differentiation. Endocrinology 122 (Suppl.), 243. abstr. 890 .

Tonetta, S.A. \& diZerega, G.S. (1986) Paracrine regulators of follicular maturation in primates. Clin. Endocr. Metab. 15, 135-156. 
Tonetta, S.A. \& diZerega, G.S. (1989) Intragonadal regulation of follicular maturation. Endocr. Rew. 10, 205-229.

Tonetta, S.A., DeVinna, R.S. \& diZerega, G.S. (1988a) Effects of follicle regulatory protein on thecal aromatase and $3 \beta$-hydroxysteroid dehydrogenase activity in medium-and large-sized pig follicles. $J$. Reprod. Fert. 82, 163-171.

Tonetta, S.A., Yanagihara, D.L., DeVinna, R.S. \& diZerega, G.S. (1988b) Secretion of follicle regulatory protcin by porcine granulosa cells. Biol. Reprod. 38, 1001-1005.

Ueno, N., Ling, N., Ying, S-Y., Esch, F., Shimasaki, S. \& Guillemin, R. (1987) Isolation and partial characteriz- ation of follistatin, a novel Mr 35,000 monomeric protein which inhibits the release of follicle stimulating hormone. Proc. natn. Acad. Sci. USA 84, 8282-8286.

Ying, S-Y. (1987) Inhibins and activins: chemical properties and biological activity. Proc. natn. Acad. Sci. USA 186, 253-265.

Ying, S-Y. (1988) Inhibins, activins, and follistatins: Gonadal proteins modulating the secretion of folliclestimulating hormone. Endocrine Rev. 9, 267-293.

Ying, S-Y., Becker, A., Swanson, G., Tan, P., Ling, N., Esch, F., Ueno, N., Shimasaki, S. \& Guillemin, R. (1987) Follistatin specifically inhibits pituitary follicle stimulating hormone release in vitro. Biochem. Biophys. Res. Commun. 149, 133-139. 